J. Japan. Assoc. Min.

Petr. Econ. Geol.

$82,177-188,1987$

\title{
The petrology of the Chuquicamata Plutonic Complex, Chile
}

\author{
M.A. PARAdA*, I. Aracena** and Hisao TanakA*** \\ * Departamento de Geología y Geofísica, Universidad de Chile, \\ Casilla 13518, Correo 21, Santiago, Chile. \\ **CODELCO-Chile, Superintendencia de Geología, Div. \\ Chuquicamata, Chile. \\ ***Department of Earth Sciences, Yamagata University, \\ Yamagata 990, Japan.
}

\begin{abstract}
The Tertiary Chuquicamata Plutonic Complex, in which the Chuquicamata porphyry copper deposit occurs, is described from petrographical and mineralogical viewpoints. The complex is composed of the Fortuna Monzonite, Chuqui Granite Porphyry and Este Monzogranite. The Chuqui Granite Porphyry, the host rock of the mineralization, is divided into the porphyry I, II and III. Potassic, propylitic and phyllic alteration of varying degrees prevails throughout the complex.

Amphibole from the Fortuna Monzonite, the most basic rock type, has $\mathrm{Mg} /(\mathrm{Mg}+\mathrm{Fe}$ *) ratios higher than 0.74 and high $\mathrm{Si}$ atoms. Biotites contained in all the rock types exhibit $\mathrm{Mg} /\left(\mathrm{Mg}+\mathrm{Fe}^{*}\right)$ ratios higher than 0.58 . The high $\mathrm{Mg} /\left(\mathrm{Mg}+\mathrm{Fe}^{*}\right)$ ratios of the mafic silicates, high $\mathrm{Fe}_{2} \mathrm{O}_{3} / \mathrm{FeO}$ whole rock ratios, the presence of magnetite and high magnetic susceptibility indicate that the Chuquicamata rocks were formed at high oxygen fugacities between the Qz-Mt-Fa and $\mathrm{Mt}-\mathrm{Hm}$ oxygen buffer reactions. Two-feldspar geothermometer of Stormer (1975) gave fairly low equilibration temperatures from $550^{\circ}$ to $350^{\circ} \mathrm{C}$. The lowest temperatures were obtained for the twofeldspar pairs from the porphyry $\mathrm{I}$, which is consistent with the lowest $\mathrm{TiO}_{2}$ contents of their biotites.

The early plagioclase crystallization in the Fortuna Monzonite, and the quartz crystallization before biotite in the Chuqui Granite Porphyry imply that the Chuquicamata magmas were not saturated with $\mathrm{H}_{2} \mathrm{O}$ throughout their entire congelation. Because only a little amount of magmatic fluid is available, the presence of meteoric fluids is speculated for the cause of the hydrothermal alteration and subsolidus equilibration.
\end{abstract}

\section{Introduction}

The Chuquicamata porphyry copper deposit occurs in the Chuquicamata Plutonic Complex (Perry, 1952; Aracena, 1981), which consists of the Fortuna Monzonite, Chuqui Granite Porphyry (ChGP) and Este Monzogranite from west to east (Fig. 1). The Chuquicamata Plutonic Complex is located in the northern part $\left(\sim 22^{\circ} 30^{\prime} \mathrm{S}\right)$ of a discontinuous NS-trending Tertiary plutonic belt, extending from $22^{\circ}$ to $25^{\circ} \mathrm{S}$. The wall rocks of the complex are Paleozoic metamorphic and granitic rocks, and Jurassic-Cretaceous volcanic and sedimentary rocks.

The ChGP is the host rock of the copper mineralization and covers the area between the Fortuna Monzonite and Este Monzogranite. The ChGP exhibits a gradational contact with the Este Monzogranite on the east. It is cut by the Oeste Fault, which is in turn in contact with the Fortuna Monzonite.

(Manuscript received, January 23, 1987 ;

accepted for publication, March 20, 1987 ) 

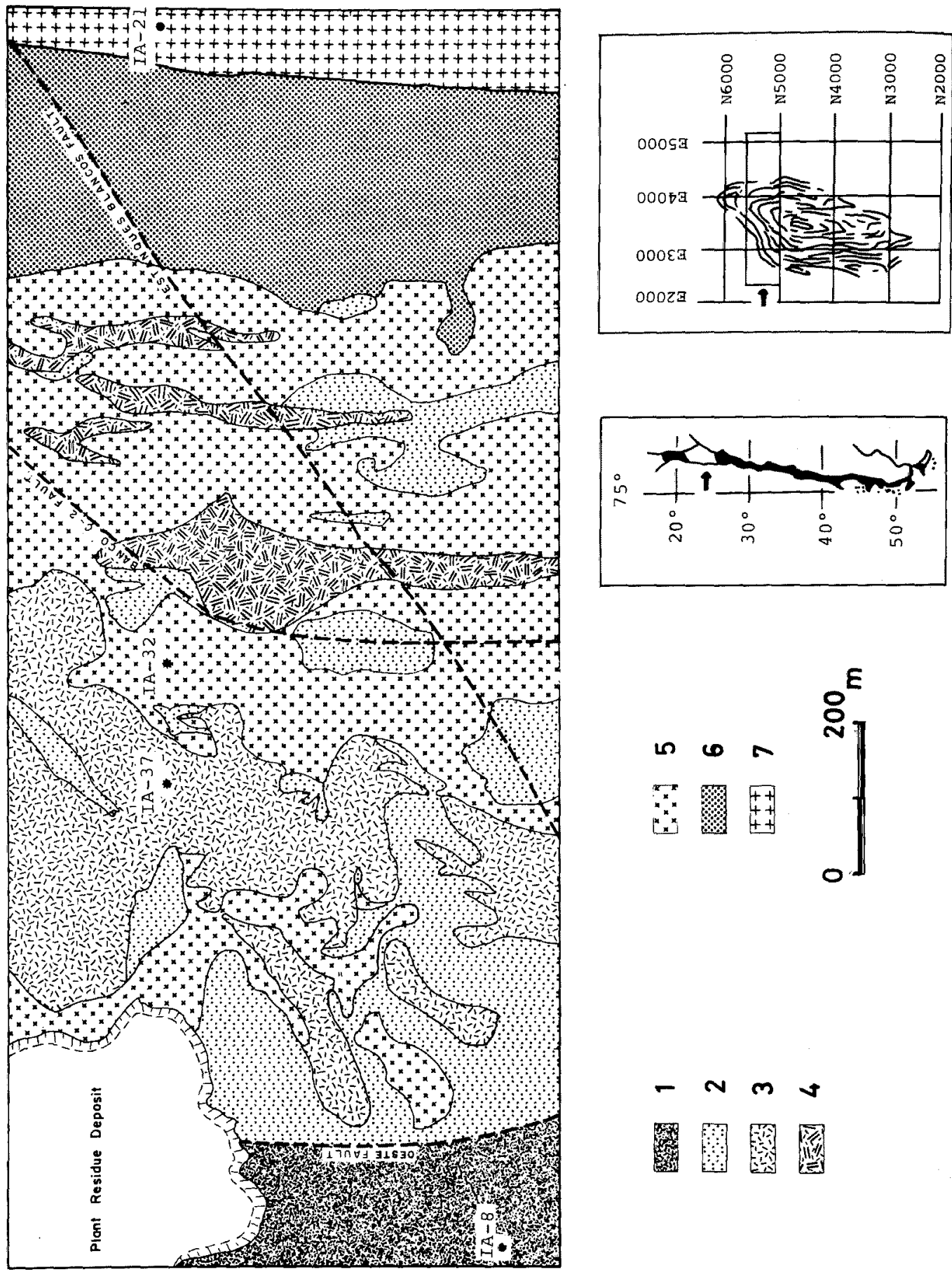

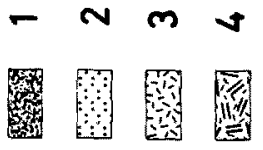


Hydrothermal alteration, which produced potassic, propylitic and quartz-sericite rocks, is commonly recognized throughout the complex (Pallauta, 1980; Aracena, 1981; Alvarez and Aracena, 1985).

In this paper, the geological and petrographical outline of the complex, and the chemistry of rock and mineral are presented. The mineral chemistry indicates equilibration under subsolidus conditions. The presence of meteoric fluid is speculated for the cause of the subsolidus equilibration and hydrothermal alteration.

\section{Outline of the Chuquicamata Plutonic Com- plex}

\section{Fortuna Monzonite}

The Fortuna Monzonite is distributed to the west of the Oeste Fault. It commonly exhibits a medium-grained, equigranular texture. Some rocks, however, have a porphyritic texture and those near the Oeste Fault show cataclastic features. The Fortuna Monzonite is composed of plagioclase $(40-55 \%), \mathrm{K}$-feldspar $(<30 \%)$, quartz (13-25\%), brown biotite (3$6 \%$ ), pale green amphibole (1-7\%) and a minor amount of apatite, magnetite, sphene and zircon. Chlorite, sericite and K-feldspar often replace the plagioclase. Secondary epidote and zeolite are widespread in the main primary minerals, and alunite in the plagioclase. Two $\mathrm{K}-\mathrm{Ar}$ biotite ages gave $36.2 \pm 1.4$ and $38.0 \pm 0.3$ Ma (Aracena, 1981). Magnetic susceptibility of the Fortuna Monzonite is high, varying from 620 to $960 \times 10^{-6} \mathrm{emu} / \mathrm{g}$ (Ishihara et al., 1984).

\section{Este Monzogranite}

The Este Monzogranite seems to intrude into Lower Paleozoic metamorphic rocks on the east of the studied area. The Este Monzogranite distributing near the area of the ChGP displays similar petrographical features to the latter.

The Este Monzogranite is medium-grained and has color index of about 10 . It consists of plagioclase $(32-50 \%), \quad \mathrm{K}$-feldspar $(25-40 \%)$, quartz $(12-30 \%)$, brown biotite $(3-8 \%)$, pale green amphibole $(<1 \%)$ and accessory minerals, such as sphene, apatite, magnetite and zircon. As alteration minerals, it contains chlorite, sericite, kaolin, montmorillonite, and minor epidote and calcite.

\section{Chuqui Granite Porphyry (ChGP)}

The ChGP consists of monzogranite porphyry and granodiorite porphyry, which often have undergone intense hydrothermal alteration and mineralization. In several places, quartz-sericite rocks, up to $20 \mathrm{vol} . \%$ of the ChGP, were formed by the alteration. From a petrographical standpoint, the ChGP is divided into three subtypes; granodiorite porphyry (porphyry I), monzogranite porphyry (porphyry II), and monzogranite porphyry with phenocrysts of two different sizes (porphyry III) (Aracena, 1981).

The porphyry $I$ is the most abundant rock type, being about 45 vol.\% of the ChGP. As phenocrystic minerals, it contains plagioclase, $\beta$-quartz and $\mathrm{K}$-feldspar. An aggregate of small brown biotite, up to $4 \mathrm{~mm}$ in length, is sometimes found. The groundmass, constitut-

Fig. 1. Geological map of the northern part of the Chuquicamata Plutonic Complex.

1, Fortuna Monzonite; 2 , quartz-sericite rocks; 3 , porphyry II ; 4, porphyry III ; 5 , porphyry 1; 6, Este Monzogranite and ChGP undifferentiated; 7, Este Monzogranite. Solid circles, surface samples; stars, location of high-angle drilling holes where samples IA-37 (porphyry I) and IA-32 (porphyry III) were obtained. Inset : the Chuquicamata ore pit and the studied area. The Chuquicamata rocks have undergone hydrothermal alteration in varying degrees. Potassic alteration prevails throughout the complex, propylitic alteration in the eastern part, and phyllic alteration immediately east of the Oeste Fault. Quartz-sericite rocks were formed by the phyllic alteration. 
ing $5-10$ vol.\% of rock sample, is composed of quart $z$ and $\mathrm{K}$-feldspar, which shows a sugary equigranular texture. The porphyry I has a KAr biotite age of $33.6 \pm 0.9 \mathrm{Ma}$.

The porphyry II, which forms 25 vol.\% of the ChGP, is distributed in the western part. It intrudes into the porphyry I. A K-Ar biotite age of the porphyry II is $31.8 \pm 0.9 \mathrm{Ma}$, being slightly younger than that of the porphyry $I$. Plagioclase and quartz are the main phenocrystic minerals. The groundmass, being present in a small amount, consists of fine-grained quart $z$, feldspar and minor biotite, and exhibits a sugary equigranular texture.

The porphyry III, occupying 10 vol. $\%$ of the ChGP, occurs as several quadrilateral bodies elongated in a N-S direction in the eastern part. It intrudes into the porphyry I. The contact of the porphyry III with the porphyry II was not observed. The porphyry III has a $\mathrm{K}$-Ar biotite age of $33.8 \pm 1.3 \mathrm{Ma}$. It contains plagioclase, $\beta$-quartz and trace amphibole as phenocrysts that display a bimodal frequency in grain size; that is crystals larger than $3.0 \mathrm{~mm}$ and those of $1.0-2.0 \mathrm{~mm}$. It also has poikilitic $\mathrm{K}$-feldspar megacrysts which may be primary. The groundmass, which constitutes about $15 \%$ of rock sample, is composed of quartz, K-feldspar, plagioclase and brown biotite.

\section{Altered Rocks}

The Chuquicamata rocks have been affected by potassic, propylitic and phyllic alteration in varying degrees (Aracena, 1981). The potassic alteration is the most extensive, affecting more than 50 vol.\% of the ChGP and almost completely the Fortuna Monzonite. Most of the potassic altered rocks were overprinted by late propylitic and/or phyllic alteration in some degree. The propylitic altered rocks are prevalent in the eastern part of the studied area. The phyllic alteration is closely related to faults and fractures. The phyllic altered (quartz-sericite) rocks are well distributed in the area immediately east of the Oeste Fault.

The potassic alteration produced a secondary mineral assemblage of biotite, quartz, $\mathrm{K}$ feldspar, magnetite and carbonates. The amphibole pseudomorph replaced by biotite is found in intensely altered rocks. Secondary $\mathrm{K}$-feldspar occurs as interstitial pertite or as veins.

The propylitic alteration is characterized by the secondary mineral assemblage of chlorite, epidote, magnetite, rutile and pyrite.

The phyllic alteration completely destroyed the original rock character and produced quartz-sericite rocks.

The copper mineralization is mainly hosted in the potassic and phyllic altered rocks of the ChGP. The ore mineral assemblage in the potassic altered rocks is chalcopyrite, bornite, digenite, pyrite and molybdenite. The ore minerals in the phyllic altered rocks are chalcopyrite, enargite, pyrite and molybdenite.

\section{Whole rock chemistry}

Alvarez and Aracena (1985) presented chemical analyses of the Chuquicamata rocks. Most of the $\mathrm{SiO}_{2}$ contents of the analyses are in a range from 62 to $72 \mathrm{wt} . \%$. Representative analyses are shown in Table 1. They are characterized by high $\mathrm{Na}_{2} \mathrm{O}(3.65-5.71$ wt.\%) and $\mathrm{Fe}_{2} \mathrm{O}_{3} / \mathrm{FeO}(0.58-4.08)$, which is a characteristic of Chilean Tertiary granitic rocks (Ishihara $e t$ al., 1984). Contents of $\mathrm{CaO}$ and $\mathrm{K}_{2} \mathrm{O}$ vary in wide ranges, considering a restricted spread of $\mathrm{SiO}_{2}$. The Fortuna Monzonite is slightly poorer in $\mathrm{SiO}_{2}$ than the ChGP. Aracena (1981) pointed out that the ChGP was formed from the Fortuna Monzonite by plagioclase-dominated fractionation.

\section{Mineral chemistry}

Four rock samples were selected for a 
Table 1. Representative chemical compositions of the Chuquicamata rocks

\begin{tabular}{|c|c|c|c|c|c|c|c|c|c|c|}
\hline & \multicolumn{2}{|c|}{$\begin{array}{l}\text { Fortuna } \\
\text { Monzonite }\end{array}$} & \multicolumn{2}{|c|}{ Porphyry I } & \multicolumn{2}{|c|}{ Porphyry II } & \multicolumn{2}{|c|}{ Porphyry III } & \multicolumn{2}{|c|}{$\begin{array}{c}\text { Este } \\
\text { Monzogranite }\end{array}$} \\
\hline & $I A-7$ & $I A-8$ & $I A-37$ & IA -63 & IA -27 & $I A-39$ & $I A-32$ & IA -44 & $I A-10$ & $I A-14$ \\
\hline $\mathrm{SiO}_{2}$ & 64.30 & 65.81 & 69.24 & 72.65 & 64.94 & 72.42 & 69.80 & 67.62 & 72.33 & 72.65 \\
\hline $\mathrm{TiO}_{2}$ & 0.40 & 0.39 & 0.10 & 0.18 & 0.07 & 0.04 & 0.14 & 0.22 & 0.20 & 0.14 \\
\hline $\mathrm{Al}_{2} \mathrm{O}_{3}$ & 15.72 & 15.74 & 14.73 & 14.04 & 15.72 & 12.93 & 15.17 & 15.80 & 13.29 & 13.63 \\
\hline $\mathrm{Fe}_{2} \mathrm{O}_{3}$ & 2.57 & 2.14 & 0.77 & 2.19 & 1.12 & 1.37 & 1.32 & 3.92 & 1.26 & 0.86 \\
\hline $\mathrm{FeO}$ & 2.04 & 2.12 & 1.32 & 1.91 & 0.69 & 0.54 & 1.37 & 0.96 & 1.41 & 1.30 \\
\hline Mno & 0.07 & 0.06 & 0.07 & 0.03 & 0.04 & 0.01 & 0.02 & 0.01 & 0.04 & 0.03 \\
\hline MgO & 1.42 & 1.39 & 0.57 & 0.45 & 0.43 & 0.22 & 0.50 & 0.38 & 0.67 & 0.78 \\
\hline $\mathrm{CaO}$ & 4.41 & 3.70 & 0.96 & 0.53 & 3.17 & 0.73 & 2.01 & 0.38 & 1.21 & 1.33 \\
\hline $\mathrm{Na}_{2} \mathrm{O}$ & 4.60 & 4.70 & 3.80 & 4.23 & 4.05 & 3.65 & 4.87 & 5.71 & 4.42 & 5.80 \\
\hline $\mathrm{K}_{2} \mathrm{O}$ & 2.71 & 2.70 & 5.72 & 3.25 & 4.44 & 5.88 & 3.18 & 2.90 & 2.82 & 1.03 \\
\hline $\mathrm{H}_{2} \mathrm{O}$ & 0.47 & 0.49 & 1.53 & 0.82 & 2.02 & 1.45 & 0.16 & 1.25 & 1.07 & 1.19 \\
\hline $\mathrm{P}_{2} \mathrm{O}_{5}$ & 0.19 & 0.18 & 0.12 & 0.10 & 0.09 & 0.07 & 0.13 & 0.10 & 0.07 & 0.06 \\
\hline $\mathrm{CO}_{2}$ & & & 0.14 & 0.18 & 1.28 & & 0.98 & 0.15 & 0.32 & 0.53 \\
\hline Total & 98.90 & 99.42 & 99.07 & 100.56 & 98.06 & 99.31 & 99.65 & 99.40 & 99.11 & 99.33 \\
\hline
\end{tabular}

The chemical compositions are taken from Alvarez and Aracena (1985) and complete data list are available from the authors on request.

study of mineral chemistry; that is IA-8 (Fortuna Monzonite), IA-21 (Este Monzogranite), IA-37 (porphyry I) and IA-32 (porphyry III). Mineral analyses were done with a HITACHI model X-560 electron-probe microanalyser using an energy-dispersive $\mathrm{X}$-ray analytical system at Tohoku University. Correction procedures and the resultant precision for this method were described by Fujimaki and Aoki (1980). FeO in the analyses is total iron expressed as $\mathrm{FeO}$.

\section{Amphibole}

Only amphiboles from the Fortuna Monzonite were analysed, because the other rocks are almost lacking in or completely free of amphiboles. In the Fortuna Monzonite, pale green amphiboles occur as large subhedral crystals up to $5 \mathrm{~mm}$ and as small anhedral ones. Commonly they are replaced partially by brown biotite from the margin. Chemical compositions of the Fortuna amphiboles are presented in Table 2. No systematic compositional vari- ation within individual crystals have been observed. The analysed crystals have high $\mathrm{Si}$ atoms and $\mathrm{Mg} /\left(\mathrm{Mg}+\mathrm{Fe}^{*}\right)\left(\mathrm{Fe}^{*}\right.$ signifies total iron as $\mathrm{Fe}^{2+}$ ) ratios, being plotted in fields of actinolite and actinolitic hornblende on the classification diagram of Leake (1978) (Fig. 2).

\section{Biotite}

In the Fortuna Monzonite and Este Monzogranite, biotite developed as subhedral brown crystals of 1 to $2 \mathrm{~mm}$ long. Biotite in the ChGP occurs either as anhedral brown flakes or as an aggregate of small brown crystals. Chemical compositions of biotites are given in Table 3. The analysed biotites have relatively high $\mathrm{Mg} /\left(\mathrm{Mg}+\mathrm{Fe}^{*}\right)$ ratios, being higher than 0.58 (Fig. 3). $\mathrm{TiO}_{2}$ content in biotites varies in a wide range from $4.0-5.0 \mathrm{wt} . \%$ in the Fortuna Monzonite of 1.1-1.3 wt.\% in the porphyry I. Biotites from the Fortuna Monzonite exhibit a slight increase in $\mathrm{TiO}_{2}$ toward the crystal rim. Biotites from the porphyry I have higher $\mathrm{Mg}$ / $\left(\mathrm{Mg}+\mathrm{Fe}^{*}\right)$ ratio and $\mathrm{Al}_{2} \mathrm{O}_{3}$ content than biotites 
Table 2. Chemical compositions and structual formulae of amphiboles (based on 23 oxygens)

\begin{tabular}{|c|c|c|c|c|c|c|c|c|}
\hline & $\mathrm{C}-$ & $-r$ & $\mathrm{c}-$ & $-r$ & $c-$ & $-r$ & $\mathrm{c}-$ & $-r$ \\
\hline $\mathrm{SiO}_{2}$ & 52.93 & 53.17 & 52.21 & 52.08 & 56.61 & 52.78 & 52.61 & 53.45 \\
\hline $\mathrm{TiO}_{2}$ & 0.72 & 0.68 & 0.67 & 0.70 & 0.48 & 0.60 & 0.64 & 0.51 \\
\hline $\mathrm{Al}_{2} \mathrm{O}_{3}$ & 4.32 & 3.84 & 3.85 & 4.01 & 3.95 & 3.89 & 3.85 & 3.42 \\
\hline $\mathrm{FeO}$ & 9.68 & 9.57 & 10,20 & 10.08 & 8.65 & 10.12 & 10.08 & 9.77 \\
\hline $\mathrm{MnO}$ & 0.59 & 0.53 & 0.47 & 0.53 & 0.44 & 0.57 & 0.58 & 0.54 \\
\hline MgO & 16.66 & 17.06 & 16.72 & 16.50 & 15.41 & 16.58 & 16.70 & 17.05 \\
\hline $\mathrm{CaO}$ & 11.69 & 11.93 & 12.17 & 12.04 & 10.86 & 11.73 & 12.04 & 12.09 \\
\hline $\mathrm{Na}_{2} \mathrm{O}$ & 0.75 & 0.52 & 0.92 & 0.96 & 0.79 & 0.83 & 0.88 & 0.78 \\
\hline $\mathrm{k}_{2} \mathrm{O}$ & 0.44 & 0.31 & 0.35 & 0.36 & 0.35 & 0.29 & 0.32 & 0.30 \\
\hline Total & 97.78 & 97.61 & 97.56 & 97.26 & 97.54 & 97.39 & 97.70 & 97.91 \\
\hline Si & 7.537 & 7.572 & 7.494 & 7.495 & 7.933 & 7.561 & 7.527 & 7.600 \\
\hline$A I^{I V}$ & 0.463 & 0.428 & 0.506 & 0.505 & 0.067 & 0.439 & 0.473 & 0.400 \\
\hline$A I^{V I}$ & 0.262 & 0.216 & 0.145 & 0.175 & 0.586 & 0.217 & 0.177 & 0.173 \\
\hline $\mathrm{Ti}$ & 0.077 & 0.073 & 0.072 & 0.076 & 0.051 & 0.065 & 0.068 & 0.055 \\
\hline $\mathrm{Fe}$ & 1.152 & 1.140 & 1.224 & 1.213 & 1.014 & 1.213 & 1.207 & 1.162 \\
\hline $\mathrm{Mn}$ & 0.071 & 0.064 & 0.057 & 0.065 & 0.052 & 0.069 & 0.070 & 0.065 \\
\hline $\mathrm{Mg}$ & 3.535 & 3.621 & 3.578 & 3.539 & 3.220 & 3.540 & 3.561 & 3.613 \\
\hline $\mathrm{Ca}$ & 1.783 & 1.821 & 1.872 & 1.857 & 1.630 & 1.800 & 1.846 & 1.857 \\
\hline $\mathrm{Na}$ & 0.208 & 0.142 & 0.257 & 0.266 & 0.213 & 0.232 & 0.244 & 0.215 \\
\hline K & 0.079 & 0.057 & 0.065 & 0.065 & 0.063 & 0.053 & 0.059 & 0.055 \\
\hline Total & 15.167 & 15.134 & 15.270 & 15.256 & 14.829 & 15.189 & 15.232 & 15.195 \\
\hline $1 \mathrm{~g} /\left(\mathrm{Mg}+\mathrm{Fe} \mathrm{e}^{*}\right)$ & 0.754 & 0.761 & 0.745 & 0.745 & 0.761 & 0.745 & 0.747 & 0.757 \\
\hline
\end{tabular}

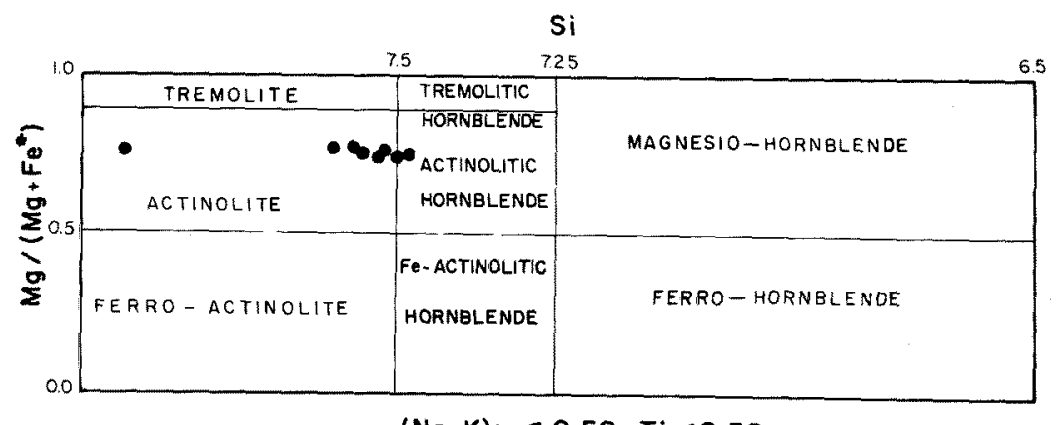

$(\mathrm{Na}+\mathrm{K})_{\mathrm{A}}<0.50 ; \mathrm{Ti}<0.50$

Fig. 2. Classification of the analysed amphiboles from the Fortuna Monzonite after Leake (1978).

from the other rock types.

3. Feldspars

Plagioclases in all the rock types are usually euhedral to subhedral crystals, which began to crystallize at an early stage of crystallization. $\mathrm{K}$-feldspar, which usually occur as interstitial crystals or megacrysts, on the other hand, crystallized at a late stage. The compositions 
Table 3. Chemical compositions and structural formulae of biotites (based on 22 oxygens)

\begin{tabular}{|c|c|c|c|c|c|c|c|c|c|}
\hline \multirow[b]{2}{*}{$\mathrm{SiO}_{2}$} & \multicolumn{3}{|c|}{ IA- 8} & \multicolumn{2}{|c|}{ IA -37} & \multicolumn{2}{|c|}{$I A-32$} & \multicolumn{2}{|c|}{$I A-2 I$} \\
\hline & 38.59 & 38.45 & 38.66 & 36.27 & 39.14 & 37.90 & 38.78 & 37.36 & 37.11 \\
\hline $\mathrm{TiO}_{2}$ & 4.64 & 4.95 & 4.03 & 1.16 & 1.30 & 3.46 & 3.12 & 3.61 & 3.24 \\
\hline $\mathrm{Al}_{2} \mathrm{O}_{3}$ & 13.67 & 14.02 & 13.17 & 19.60 & 17.02 & 14.06 & 13.64 & 14.88 & 15.93 \\
\hline $\mathrm{FeO}$ & 14.98 & 16.25 & 14.69 & 12.56 & 10.97 & 15.14 & 15.42 & 17.83 & 17.53 \\
\hline Mno & & & 0.30 & 0.25 & 0.07 & 0.14 & 0.17 & 0.48 & 0.48 \\
\hline $\mathrm{MgO}$ & 15.35 & 13.50 & 15.53 & 16.03 & 16.85 & 14.82 & 14.99 & 13.55 & 13.60 \\
\hline $\mathrm{CaO}$ & 0.18 & 0.35 & 0.24 & 0.33 & 0.30 & 0.18 & 0.27 & 0.19 & 0.25 \\
\hline $\mathrm{Na}_{2} \mathrm{O}$ & & & 0.30 & 0.22 & 0.15 & 0.52 & 0.28 & & \\
\hline $\mathrm{K}_{2} \mathrm{O}$ & 9.45 & 8.64 & 9.10 & 9.53 & 9.98 & 9.43 & 9.36 & 8.10 & 7.82 \\
\hline Total & 96.86 & 96.16 & 96.02 & 95.95 & 95.78 & 95.65 & 96.03 & 96.00 & 95.96 \\
\hline Si & 5.661 & 5.688 & 5.719 & 5.313 & 5.684 & 5.655 & 5.754 & 5.578 & 5.522 \\
\hline$A 1^{I V}$ & 2.339 & 2.312 & 2.281 & 2.687 & 2.316 & 2.345 & 2.246 & 2.422 & 2.478 \\
\hline$A 1^{V I}$ & 0.026 & 0.132 & 0.015 & 0.696 & 0.596 & 0.127 & 0.138 & 0.197 & 0.315 \\
\hline $\mathrm{Ti}$ & 0.512 & 0.550 & 0.449 & 0.128 & 0.142 & 0.388 & 0.348 & 0.406 & 0.363 \\
\hline $\mathrm{Fe}$ & 1.838 & 2.011 & 1.818 & 1.539 & 1.332 & 1.889 & 1.914 & 2.227 & 2.181 \\
\hline $\mathrm{Mn}$ & & & 0.038 & 0.031 & 0.009 & 0.018 & 0.022 & 0.060 & 0.061 \\
\hline $\mathrm{Mg}$ & 3.356 & 2.976 & 3.425 & 3.500 & 3.648 & 3.296 & 3.316 & 3.015 & 3.017 \\
\hline $\mathrm{Ca}$ & 0.028 & 0.055 & 0.039 & 0.052 & 0.046 & 0.030 & 0.042 & 0.030 & 0.039 \\
\hline $\mathrm{Na}$ & & & 0.087 & 0.062 & 0.043 & 0.150 & 0.079 & & \\
\hline $\mathrm{K}$ & 1.769 & 1.630 & 1.717 & 1.781 & 1.849 & 1.796 & 1.772 & 1.543 & 1.485 \\
\hline Total & 15.529 & 15.354 & 15.588 & 15.789 & 15.665 & 15.694 & 15.631 & 15.478 & 15.461 \\
\hline$\left(\mathrm{Mg}+\mathrm{Fe}^{*}\right)$ & 0.646 & 0.597 & 0.653 & 0.695 & 0.733 & 0.636 & 0.634 & 0.575 & 0.580 \\
\hline
\end{tabular}

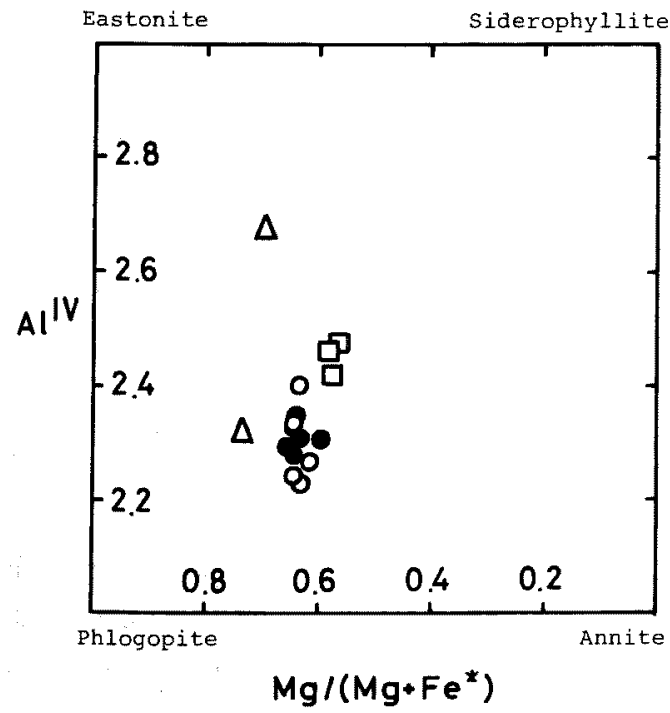

Fig. 3. Compositions of biotites in the phlogopiteannite-eastonite-siderophyllite quadrilateral. Closed circle, Fortuna Monzonite; square, Este Monzogranite; triangle, porphyry I; open circle, porphyry III. 


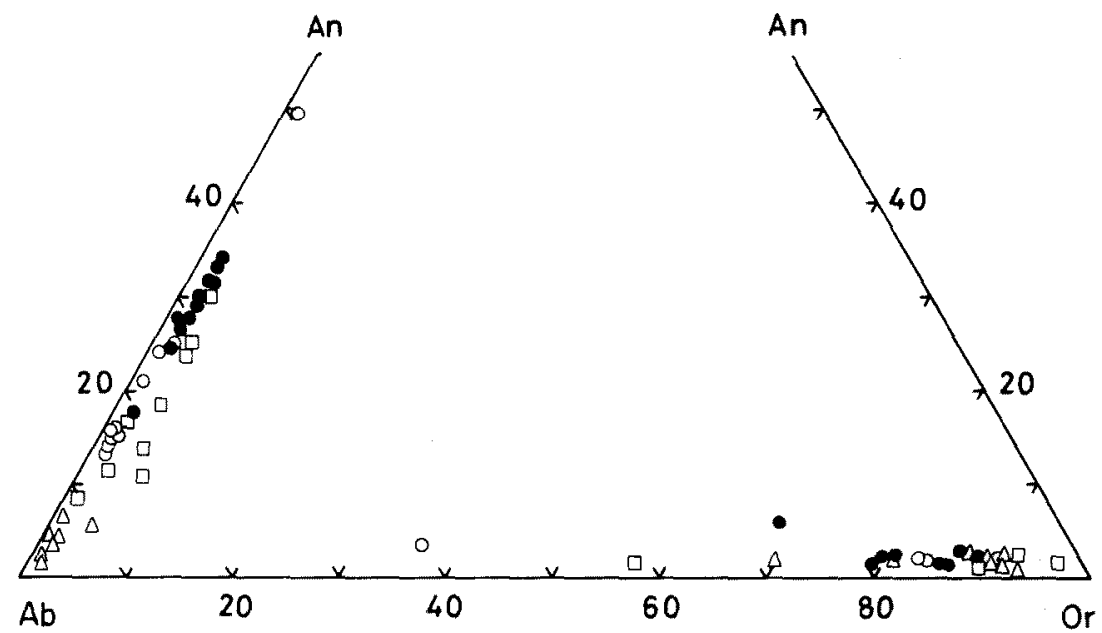

Fig. 4. Compositions of feldspars, projected on the anorthite (An)-albite (Ab)-orthoclase (Or) diagram. The same symbols as in Fig. 3.

of feldspars are plotted in Fig. 4, and their representative analyses are presented in Table 4. The analysed plagioclases commonly show a decrease in the An content toward the crystal rim (normal zoning with respect to the An content). Plagioclases from the Fortuna Monzonite are the most calcic $\left(\mathrm{An}_{18-50}\right)$ and those from the porphyry I the most sodic $\left(A n_{2-15}\right)$. The analysed $\mathrm{K}$-feldspars display a very wide range in the Or content, though most of them have Or contents higher than 80 .

\section{Magnetite}

A small amount of magnetite occurs as independent small grains in the Fortuna Monzonite and Este Monzogranite. Chemical compositions of magnetites are given in Table 5. The analysed magnetites are composed predominantly of $\mathrm{Fe}_{3} \mathrm{O}_{4}$, with ulvöspinel component, calculated by the method of Stormer (1983), less than $1 \%$.

\section{Equilibration under high oxygen fugacities and low temperatures}

The chemistry of rock and mineral, mineral assemblage and magnetic susceptibility would provide valuable information on conditions of equilibration. The high $\mathrm{Fe}_{2} \mathrm{O}_{3} / \mathrm{FeO}$ whole rock ratios, high $\mathrm{Mg} /\left(\mathrm{Mg}+\mathrm{Fe}^{*}\right)$ ratios of the amphibole and biotites, the presence of magnetite and high magnetic susceptibility indicate that the Chuquicamata rocks were formed at high oxygen fugacities (Ishihara, 1981). Equilibration temperatures-oxygen fugacities were evaluated for biotite-K-feldspar-magnetite assemblage from the Chuquicamata rocks, using the equation given by Hewitt and Wones (1981). The calculated equilibration tempera* tures-oxygen fugacities cover a narrow band between the $\mathrm{Qz}-\mathrm{Mt}-\mathrm{Fa}$ and $\mathrm{Mt}-\mathrm{Hm}$ oxygen buffer curves (Fig. 5).

Equilibration temperatures for contiguous plagioclase and $\mathrm{K}$-feldspar pairs have been evaluated using the two-feldspar geothermometer of Stormer (1975). The calculated temperatures for the feldspar pairs are low and within a range from $550^{\circ}$ to $350^{\circ} \mathrm{C}$. The calculated temperatures for the Fortuna Monzonite are considerably higher than those for the porphyry I (Fig. 6). The biotites from the Fortuna Monzonite are relatively rich in $\mathrm{TiO}_{2}$, whereas those from the porphyry I are poor in the oxides (Table 3 ), indicating equilibration of the latter at lower temperatures. 
Table 4. Chemical compositions of feldspars

\begin{tabular}{|c|c|c|c|c|c|c|c|c|c|c|c|c|c|c|}
\hline \multicolumn{15}{|c|}{ Plagioclase } \\
\hline & \multicolumn{4}{|c|}{ IA-8 } & \multicolumn{4}{|c|}{$I A-37$} & \multicolumn{4}{|c|}{$I A-32$} & \multicolumn{2}{|c|}{$I A-2 I$} \\
\hline & $\mathrm{c}-$ & $-x$ & $\mathrm{c}-$ & $-r$ & $c$ & $-x$ & $c=$ & $r$ & $c$ & $-r$ & $c-$ & $-r$ & $\mathrm{c}-$ & $-x$ \\
\hline $\mathrm{SiO}_{2}$ & 60.42 & 62.03 & 56.21 & 60.08 & 67.35 & 68.40 & 68.45 & 64.72 & 62.30 & 65.11 & 62.53 & 65.20 & 65.82 & 66.77 \\
\hline $\mathrm{Al}_{2} \mathrm{O}_{3}$ & 24.83 & 23.68 & 27.02 & 24.61 & 20.46 & 19.54 & 19.52 & 22.11 & 23.44 & 21.54 & 23.49 & 22.01 & 21.16 & 20.81 \\
\hline Feo & 0.16 & 0.18 & 0.24 & 0.14 & & & & & & & & & 0.10 & \\
\hline $\mathrm{CaO}$ & 6.27 & 5.77 & 10.49 & 6.66 & 1.32 & 0.38 & 0.51 & 3.14 & 5.20 & 2.88 & 4.56 & 3.48 & 2.45 & 2.43 \\
\hline $\mathrm{Na}_{2} \mathrm{O}$ & 7.67 & 8.54 & 5.69 & 7.64 & 10.48 & 11.53 & 11.25 & 9.67 & 8.94 & 10.31 & 9.13 & 10.28 & 9.85 & 9.86 \\
\hline $\mathrm{K}_{2} \mathrm{O}$ & 0.33 & 0.29 & 0.26 & 0.44 & 0.16 & 0.25 & 0.16 & 0.19 & 0.26 & 0.31 & 0.23 & 0.28 & 0.44 & 1.06 \\
\hline Total & 99.68 & 100.49 & 99.91 & 99.57 & 99.77 & 100.10 & 99.89 & 99.83 & 100.14 & 100.15 & 99.94 & 101.25 & 99.82 & 100.93 \\
\hline An & 30.5 & 26.8 & 49.7 & 31.7 & 6.4 & 1.8 & 2.4 & 15.1 & 24.0 & 13.1 & 21.3 & 15.5 & 11.8 & 11.3 \\
\hline $\mathrm{Ab}$ & 67.6 & 71.6 & 48.8 & 65.8 & 92.6 & 96.8 & 96.7 & 83.9 & 74.6 & 85.2 & 77.4 & 83.0 & 85.7 & 82.9 \\
\hline or & 1.9 & 1.6 & 1.5 & 2.5 & 1.0 & 1.4 & 0.9 & 1.0 & 1.4 & 1.7 & 1.3 & 1.5 & 2.5 & 5.8 \\
\hline
\end{tabular}

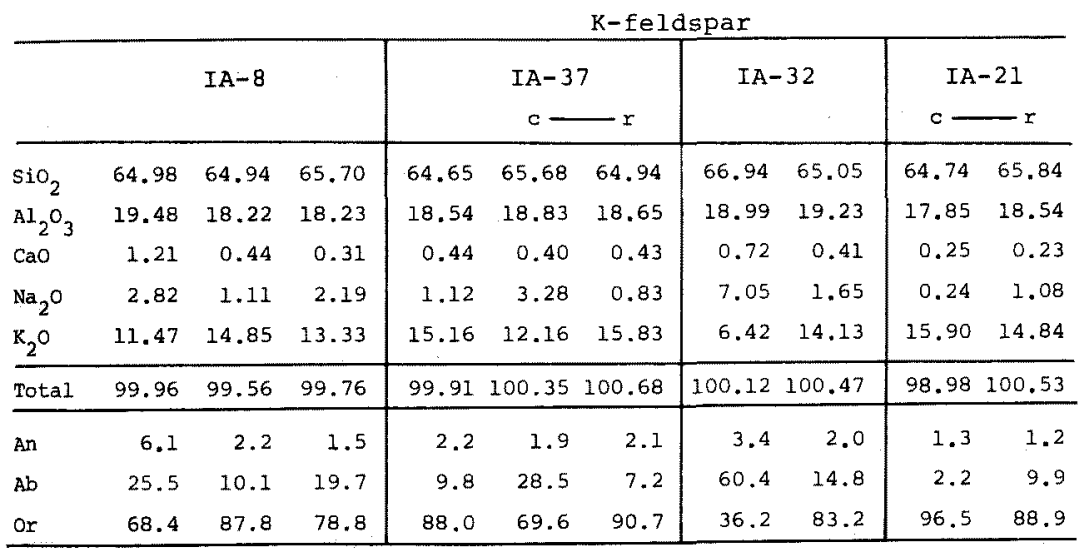

" $c$ " represents core and " $r$ " indicates rim.

Table 5. Chemical compositions of magnetites

\begin{tabular}{|c|c|c|c|c|c|c|c|}
\hline \multirow[b]{2}{*}{$\mathrm{SiO}_{2}$} & \multicolumn{5}{|c|}{$I A-8$} & \multicolumn{2}{|c|}{$I A-2 I$} \\
\hline & & 0.65 & 0.86 & 0.27 & 0.30 & 0.28 & 0.47 \\
\hline $\mathrm{TiO}_{2}^{2}$ & 0.19 & 0.22 & 0.28 & 0.19 & 0.16 & 0.20 & 0.33 \\
\hline $\mathrm{Cr}_{2} \mathrm{O}_{3}$ & 0.23 & & & & & & \\
\hline $\mathrm{v}_{2} \mathrm{O}_{3}$ & 0.59 & 0.53 & 0.70 & 0.54 & 0.73 & 0.44 & 0.44 \\
\hline $\mathrm{FeO}$ & 92.21 & 94.59 & 93.39 & 95.62 & 95.20 & 97.89 & 96.34 \\
\hline MnO & 0.43 & 0.45 & 0.50 & 0.43 & 0.43 & 0.46 & 0.44 \\
\hline Tota1 & 93.65 & 96.44 & 95.73 & 97.05 & 96.82 & 99.27 & 98.02 \\
\hline Usp & 0.6 & 0.6 & 0.8 & 0.5 & 0.4 & 0.6 & 0.9 \\
\hline
\end{tabular}




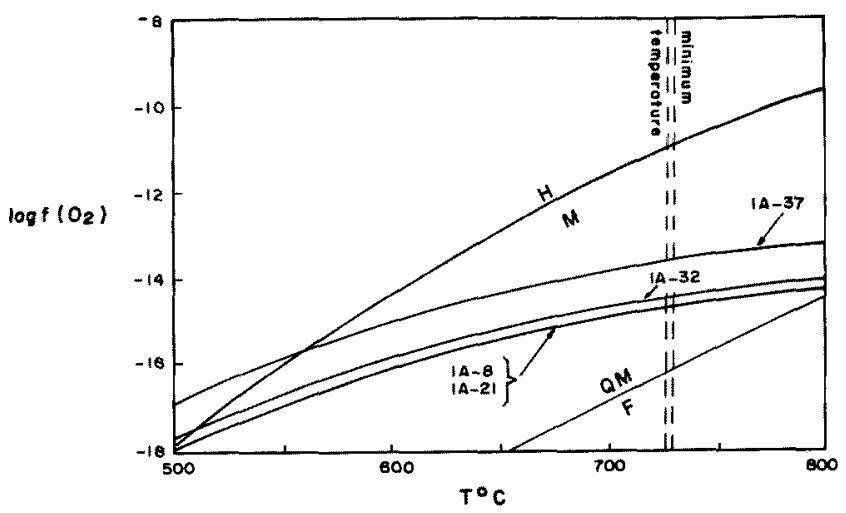

Fig. 5. Equilibration temperatures $\left(\mathrm{T}^{\circ} \mathrm{C}\right)$-oxygen fugacities $\left(\log \mathrm{f}\left(\mathrm{O}_{2}\right)\right)$ relationships obtained for the Chuquicamata biotites. HM buffer curve after Eugster and Wones (1962) ; QMF buffer curve after Hewitt (1978).

\section{Discussion : The presence of meteoric fluid at subsolidus stage}

The Chuquicamata rocks have undergone hydrothermal alteration of varying degrees, and were equilibrated under subsolidus conditions. For the cause of the hydrothermal alteration and subsolidus equilibration, the presence of meteoric fluid is speculated. The reason for the speculation is as follows.

In the Fortuna Monzonite, plagioclase crystallization started before amphibole and biotite. Naney (1983) showed experimentally that for a granodiorite system the presence of plagioclase as liquidus or near-liquidus phase instead of amphibole and biotite requires $\mathrm{H}_{2} \mathrm{O}$ undersaturated conditions. In the ChGP, biotite bagan to crystallize after quart $z$, indicating that it's magma had $\mathrm{H}_{2} \mathrm{O}$ less than 1.2 wt.\% (Maal $\phi \mathrm{e}$ and Wyllie, 1975). Granitic magma could contain $\mathrm{H}_{2} \mathrm{O}$ up to the range $4-6 \mathrm{wt} . \%$ at $1-2 \mathrm{~kb}$ of total pressures (Luth, 1976). Therefore, the condition of saturation with $\mathrm{H}_{2} \mathrm{O}$ would be attained when the crystallization was almost completed, and only a little amount of magmatic fluids would be available in the Chuquicamata Plutonic Complex. The magmatic fluids may have been not sufficient to complete the subsolidus alteration that affected the complex. Thus, the presence of meteoric fluid is speculated for the cause of the alteration. The meteoric fluid may have circulated during and/ or after the congelation of the complex. More detailed petrological and geochemical studies, especially isotopic data, are needed to test the hypothesis.

\section{Conclusions}

1. The Tertiary Chuquicamata Plutonic Complex consists of the Fortuna Monzonite, Este Monzogranite, and Chuqui Granite Porphyry which is divided into porphyry I, II and III.

2. The Chuquicamata rocks have undergone hydrothermal alteration and subsolidus equilibration. The porphyry I seems to have equilibrated at the lowest tempera. tures.

3. The chemistry of rock and mineral, the presence of magnetite and high magnetic susceptibility imply that the Chuquicamata rocks were formed at high oxygen fugacities between the $\mathrm{Qz}-\mathrm{Mt}-\mathrm{Fa}$ and $\mathrm{Mt}-$ $\mathrm{Hm}$ oxygen buffer reactions.

4. The crystallization sequence of mineral indicates that the Chuquicamata magmas 


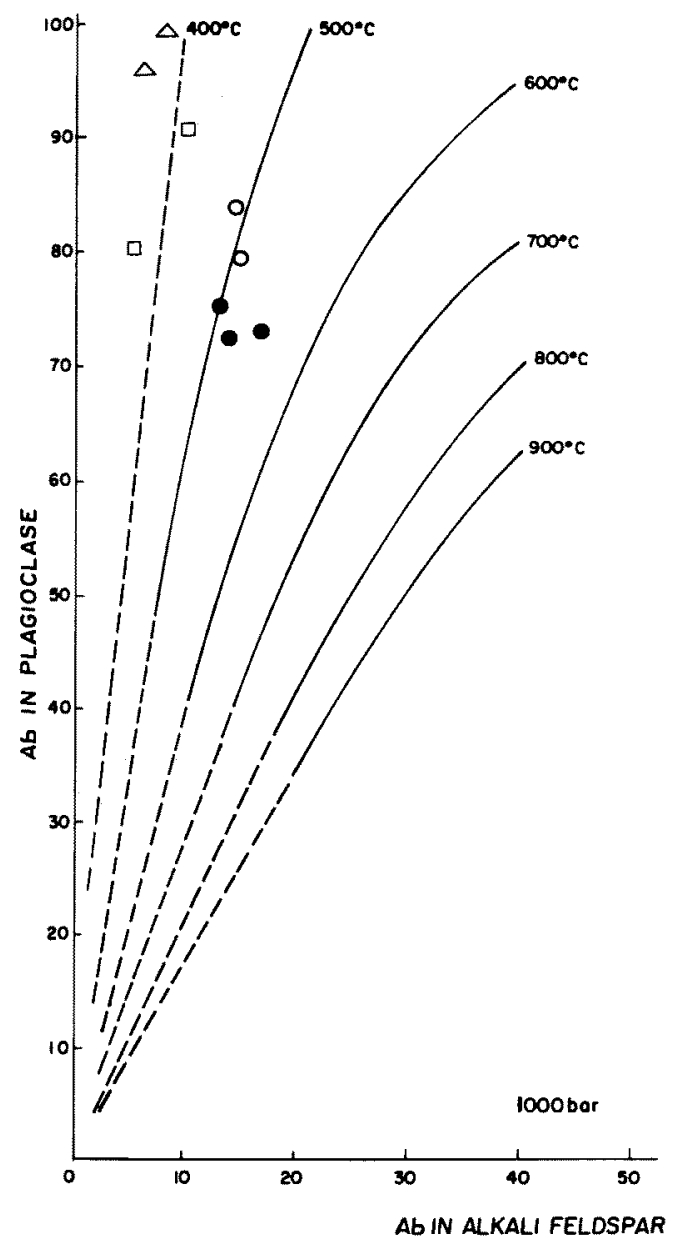

Fig. 6. Representation of contiguous plagioclase and K-feldspar compositions on the Stormer's (1975) diagram at $1 \mathrm{~kb}$. The same symbols as in Fig. 3.

were fairly anhydrous throughout the entire congelation.

5. The presence of meteoric fluids is speculated for the cause of the hydrothermal alteration and subsolidus equilibration.

Acknowledgements: We are grateful to Prof. K. Aoki who kindly allowed the use of EPMA. We are also indebted to O. Alvarez of CODELCO for his support in the initial stage of this study. The University of Chile Grant E2457 is also acknowledged. This work is a contribution to the IGCP Project 249 "Andean Magmatism".

\section{References}

Alvarez, O. and Aracena, I. (1985), Algunas con sideraciones de la petrología y alteración del Complejo Plutónico de Chuquicamata, Chile. Actas IV Congr. Geológico Chileno, T. III, área, 4, 1-30.

Aracena, 1. (1981), Geología y alteración del Com plejo Plutónico de Chuquicamata. Unpublished Thesis. Universidad de Chile.

Eugster, H.P. and Wones, D.R. (1962), Stability relations of the ferruginous biotite, annite. $J$. Petrol., 3, 82-125.

Fujimaki, H. and Aoki, K. (1980), Quantitative microanalyses of silicates, oxides and sulfides using an energy-dispersive type electron probe. Sci. Rep. Tohoku Univ., Ser. III, 14, 261-268.

Hewitt, D.A. (1978), A redetermination of the fayalite-magnetite-quart $z$ equilibrium between $650^{\circ}$ and $850^{\circ} \mathrm{C}$. Amer. J. Sci., 278, 715-724.

Hewitt, D.A. and Wones, D.R. (1981), The annitesanidine-magnetite equilibrium. Geol. Assoc. Canada, Mineral. Assoc. Canada and Canadian Geophys. Union Joint Mtg. Abs. with Programs, p. A-66.

Ishihara, S. (1981), The granitoid series and mineralization. Econ. Geol., 75th Anniversary Volume, 458-484.

Ishihara, S., Ulriksen, C.E., Sato, K., Terashima, S., Sato, T. and Endo, Y. (1984), Plutonic rocks of North-Central Chile. Bull. Geol. Surv. Japan, $35,503-536$.

Leake, B.E. (1978), Nomenclature of amphiboles. Can. Mineral., 16, 501-520.

Luth, W.C. (1976), Granitic rocks. The evolution of the crystalline rocks. (In: Bailey, D.K. and Macdonald, R., eds.). Academic Press Inc., London, 335-417.

Maaløe, S. and Wyllie, P.J. (1975), Water content of a granite magma deduced from the sequence of crystallization determined experimentally with water undersaturated conditions. Contrib. Mineral. Petrol., 52, 175-191.

Naney, M.T. (1983), Phase equilibria of rock-forming ferromagnesian silicates in granitic system. Amer. J. Sci., 283, 993-1033.

Pallauta, J. (1980), El yacimiento Chuquicamata. En: Realidad Actual y Perspectivas de la Geología de los Yacimientos de CODELCO 
Chile. Depto. de Minas, Superintendencia de Geologia, Chuquicamata. Unpublished report.

Perry, V.D. (1952), Geology of the Chuquicamata orebody. Mining Eng., 4, Dec., 1166-1169.

Stormer, J.C., Jr. (1975), A practical two-feldspar geothermometer. Amer. Mineral., 60, 667-
674.

Stormer, J.C., Jr. (1983), The effect of recalculation on estimates of temperature and oxygen fugacity from analyses of multicomponent iron-titanium oxides. Amer. Mineral, 68, $586-594$.

\section{チリ国，チュキカマタ深成岩体の岩石学的研究}

\section{M.A. Parada ・ I. Aracena ・ 田中 久雄}

チリ国，チュキカマタ深成岩体は第三紀に貫入し，斑岩銅鉱床を佯う岩体で，モンゾナイト，花崗班岩 (I, II, III)，モンゾ花凯岩に区分され，種々の程度に熱水变質作用を蒙っている。角閃石と黒雲母が $\mathrm{Mg} に$ 富丈, 岩石の $\mathrm{Fe}_{2} \mathrm{O}_{3} / \mathrm{FeO}$ 比が高く，磁鉄鉱が存在し，带磁率が高いことから，岩石は石英一磁鉄鉱-鉄かん らん石と磁鉄鉱一赤鉄鉱の緩衝反応の間の高い酸素フガシチー下で固結したと推定される。岩石は 2 長石温 度計で $550^{\circ}-350^{\circ} \mathrm{C}$ と低い平衡温度を示す。斜長石が早期に出現し，石英が黒雲母に先立って晶出している ことから，固結のほぼ全過程を通してマグマは水に不飽和であったと推定される。固結晚期の熱水变質作 用並びに低い温度での再平衡作用には天水が関与したのであらら。 